\title{
FREKUENSI VAKSINASI UNTUK PENCEGAHAN PENYAKIT PADA BUDI DAYA UDANG WNDU (Penaeus monodon Fabr.) DI TAMBAK
}

\author{
Arifuddin Tompo*), Endang Susianingsih*), dan Mun Imah Madeali*)
}

\begin{abstract}
ABSTRAK
Pencegahan dan penanggulangan penyakit pada budi daya udang windu dewasa ini dilakukan dengan cara merangsang kekebalan spesifik udang dengan menggunakan immunostimulan, namun optimalisasi penggunaannya masih perlu dilakukan. Oleh karena itu, penelitian ini dimaksudkan untuk mengoptimalisasikan penggunaan immunostimulan untuk dapat memberikan hasil yang efektif terhadap pencegahan penyakit pada budi daya udang windu. Immunostimulan yang digunakan dalam penelitian ini adalah hasil ekstraksi dari bakteri, Vibrio harveyii yang dilemahkan dengan formalin 1\% Rancangan yang digunakan dalam penelitian ini adalah Rancangan Acak Lengkap (RAL) dengan empat perlakuan: $A=$ vaksinasi empat kali sebulan, $B=$ vaksinasi dua kali sebulan, $C=$ vaksinasi sekali sebulan, dan $D=$ tanpa vaksin (kontrol) yang diulang sebanyak tiga kali. Aplikasi dolomit diberikan dua kali per minggu untuk semua perlakuan dengan dosis $5-10 \mathrm{mg} / \mathrm{L}$ untuk tiap kali penggunaan. Padat penebaran sebanyak 60.000 ekor/ha dengan pola tradisional plus. Hasil pengamatan memperlihatkan bahwa perlakuan B (vaksinasi dua kali sebulan) memberikan sintasan yang tertinggi yaitu $91,5 \%$ dengan produksi tertinggi yaitu $84,0 \mathrm{~kg}$. Pengamatan terhadap populasi bakteri Vibrio sp. pada lingkungan berada pada kisaran $10^{2}-10^{3}$ $\mathrm{cfu} / \mathrm{mL}$ yang masih layak bagi lingkungan dan budi daya udang sedangkan untuk kualitas air pada beberapa parameter juga berada pada kisaran yang layak untuk budi daya udang.
\end{abstract}

\section{ABSTRACT: Vaccine application used to prevent tiger shrimp diseases. By: Arifuddin Tompo, Endang Susianingsih, and Mun Imah Madeali}

In recent years the prevention and control of diseases on tiger shrimp culture has been stimulated by specific immunostimulan such as vaccine. How ever the optimalization used of immunostimulan have to be conducted. Based on that information, the study aims to optimalized the using of immunostimulan to give the effective result on diseases prevention on tiger shrimp culture. The immunostimulan used in this research was extracted from vibrio by formalin killed $1 \%$ with four treatments i.e. $A=$ four times of vaccination a month, $B=$ two times of vaccination a monts, $C=$ once of vaccination a month and, $D=$ control (non vaccination). Dolomite application was given two times a week for all treatments with the dosage 5-10 mg/ $L$. The results shows that the treatment $B$ (two times of vaccination a month) exhibit the survival rate i.e. $91.5 \%$ it is higher than $A, C$, and $D$ treatments with highest production $84.0 \mathrm{~kg}$. Observation on the population of Vibrio sp. value range $10^{2}-10^{3}$ cfu/mL that's normally condition both on environmental and shrimp culture, and water quality parameters was still in normal condition.

KEYWORDS: diseases, immunostimulan, vibrio, shrimp culture

*) Peneliti pada Balai Riset Perikanan Budidaya Air Payau, Maros 


\section{PENDAHULUAN}

Produksi udang windu di Indonesia pada perkembangannya mengalami penurunan dan peningkatan produksi. Data penurunan produksi ini dapat dilihat dari perkembangan ekspor untuk udang beku dari 8.188.924 kg pada Januari-September 2001 menjadi $6.757 .082 \mathrm{~kg}$ pada Januari- September 2002 atau mengalami penurunan sekitar $17,49 \%$ (Anonim, 2003). Akan tetapi produksi udang ini mengalami peningkatan yaitu dari 240.438 ton pada tahun 2003 menjadi 273.977 ton pada tahun 2004 atau mengalami peningkatan sebesar 12,24\% (Anonim, 2005). Fluktuasi perkembangan produksi udang windu ini disebabkan beberapa faktor baik eksternal dari lingkungan budi daya itu sendiri maupun faktor internal dari udang tersebut, yang salah satu di antaranya adalah adanya serangan penyakit.

Penyakit menjadi satu di antara beberapa permasalahan yang timbul dalam usaha budi daya udang windu baik pada usaha perbenihan (hatcheri) maupun pada usaha pembesaran di tambak seperti adanya penyakit bakterial yang disebabkan oleh bakteri vibrio, penyakit viral seperti Monodon Baculo Virus (MBV), White Spot Syndrom Virus (WSSV), dan parasit (Atmomarsono et al., 1993; Madeali et al., 1993; Tompo et al., 1993).

Berbagai penelitian telah dilakukan untuk mendapatkan suatu metode pencegahan dan penanggulangan penyakit pada udang windu, antara lain dengan menggunakan obat- obatan dan antibiotik (Chanratchakool et al., 1995). Penggunaan antibiotik dan bahan- bahan kimia tidak efektif lagi karena tidak memberikan hasil yang memuaskan, yaitu pada dosis tertentu justru berdampak negatif pada ikan/ udang itu sendiri, bahkan dapat menimbulkan resistensi bagi bakteri yang bersifat patogen. Sementara di lain pihak antibiotik bersifat persisten di alam dan bahkan menjadi bumerang terhadap ekspor udang Indonesia ke luar negeri.

Raa et al. (1992) menyatakan bahwa salah satu cara penanggulangan penyakit adalah dengan immunoprofilaksis yaitu meningkatkan kekebalan udang terhadap serangan penyakit yang dapat dipacu dengan pemberian immunostimulan. Penanggulangan penyakit melalui penggunaan immunostimulan ini sangat cocok diterapkan pada udang karena udang hanya memiliki sistem pertahanan non spesifik yang bersifat sementara, sehingga diperlukan stimulasi yang berulang kali untuk mengaktifkan sistem immunnya.
Salah satu immunostimulator yang dapat diberikan untuk meningkatkan kekebalan udang adalah dengan penggunaan immunostimulan yang menurut Kamiso (1996), merupakan bagian dari patogen atau substrat yang merupakan produk patogen yang bersifat antigenik, immunogenik, dan protektif. Syarat dari suatu vaksin harus bersifat immunogen, artinya harus dapat merangsang dalam pembentukan antibodi yang bertujuan untuk mendapatkan kekebalan secara aktif, di mana antigen tersebut bersama dengan sel limfoid akan membentuk antibodi (Supriyadi, 1990; Brock et al., 1994; Madigan et al., 2000).

Oleh karena itu, penelitian ini dimaksudkan untuk mengetahui frekuensi penggunaan immunostimulan yang efektif, sintasan dan produksi sebagai upaya pencegahan penyakit pada budi daya udang windu di tambak.

\section{BAHAN DAN METODE}

\section{Persiapan}

Penelitian ini dilakukan di Tambak Percobaan Maranak dengan menggunakan air yang diresirkulasi dari sumur bor dan dialirkan melalui saluran yang diaplikasikan di 12 petak tambak masing- masing dengan luas $500 \mathrm{~m}^{2}$.

Aplikasi dolomit dua kali per minggu untuk semua perlakuan dengan dosis $5-10 \mathrm{mg} / \mathrm{L}$ setiap kali penggunaan setelah ganti air mulai pada saat penebaran hingga panen. Padat penebaran tokolan yang dicobakan adalah 60.000 ekor/ ha atau $6 \mathrm{ekor} / \mathrm{m}^{2}$ dengan pola tradisional plus.

\section{Pembuatan Bakterin}

Immunostimulan yang digunakan adalah hasil ekstraksi dari bakteri Vibrio harveyii dengan kode isolat 702 produksi Balai Riset Perikanan Budidaya Air Payau, Maros (2002), yang dilakukan dengan cara melemahkan biakan murni bakteri tersebut dengan formalin 1\%yang didiamkan selama 3 jam dalam tabung reaksi. Selanjutnya dicuci dengan saline solution $0,85 \%$ melalui sentrifuge dengan kecepatan lebih dari 5.000 rpm selama 20 menit. Supernatan dibuang dan endapan dicuci dengan saline solution $0,85 \%$ kembali sampai tiga kali.

\section{Aplikasi Bakterin}

Tokolan yang digunakan terlebih dahulu direndam dengan bakterin selama kurang lebih satu jam, kemudian setiap dua minggu di- 
rangsang kekebalannya melalui pemberian pakan dengan penambahan bakterin sebanyak 2,4 $\mathrm{mL}$ dalam $1 \mathrm{~kg}$ pakan dan vitamin $\mathrm{C}$ komersial dari golongan polyphosphat diberikan dengan dosis 0,05 mg/L atau sebanyak 0,5 $\mathrm{mL}$ untuk setiap $1 \mathrm{~kg}$ pakan. Pencampuran bakterin dan vitamin C pada pakan dilakukan secara merata dengan cara penyemprotan dan kemudian dikeringanginkan selama 24 jam pada suhu ruang di dalam oven untuk mencegah terjadinya kontaminasi terutama dari jamur. Pakan diberikan dalam jumlah $10 \%$ per bobot biomassa/ hari dan menurun sesuai umur udang, dimulai saat penebaran sampai panen (83 hari pemeliharaan).

\section{Rancangan Percobaan dan Analisis Data}

Rancangan penelitian yang digunakan adalah Rancangan Acak Lengkap (RAL) dengan empat perlakuan dan tiga ulangan sehingga terdapat 12 satuan unit percobaan (Steel \& Torrie, 1989; Gaspersz, 1991), dengan perlakuan sebagai berikut: $\mathrm{A}=$ vaksinasi empat kali sebulan, $B=$ vaksinasi dua kali sebulan, $C$ = vaksinasi sekali sebulan, dan $D=$ tanpa vaksin (kontrol).

Model analisis data yang digunakan untuk menganalisis data sintasan dan produksi tokolan pada akhir penelitian, yaitu model linier additif seperti pada persamaan berikut (Steel \& Torrie, 1989).

Data yang diperoleh sebelum dianalisis keragamannya dengan menggunakan analisis keragaman (ANOVA), terlebih dahulu ditransformasi ke arcus sinus (arcsin), untuk mendapatkan penyebaran data secara distribusi normal. Jika hasil yang diperoleh menunjukkan beda nyata akan dilanjutkan dengan uji lanjut.

\section{Peubah Pengamatan}

Peubah pengamatan meliputi sintasan dan pertumbuhan udang windu, kualitas air (salinitas, pH, suhu, nitrit, amoniak, fosfat, nitrat, bahan organik total, dan besi) serta kesehatan lingkungan bakteriologis yang dilakukan tiap dua minggu hingga panen (sekitar 11 minggu).

Pengamatan terhadap sintasan (SR) udang dilakukan dengan membandingkan antara jumlah udang pada awal penelitian dan jumlah udang pada akhir penelitian, yang dihitung berdasarkan petunjuk Effendie (1979) dengan rumus:

$$
\mathrm{SR}=\frac{\mathrm{Nt}}{\mathrm{No}} \times 100 \%
$$

di mana:

$\mathrm{SR}=$ Tingkat sintasan (\%)

$\mathrm{Nt}=$ Jumlah udang pada akhir penelitian (ekor)

No $=$ Jumlah udang pada awal penelitian (ekor)

\section{HASIL DAN BAHASAN}

Pengaruh perbedaan frekuensi vaksinasi dengan penggunaan bakterin serta penambahan vitamin $\mathrm{C}$ dapat diketahui dari respon sintasan udang windu pada akhir penelitian yang dapat dilihat pada Tabel 1 .

Tabel 1 menunjukkan tingkat sintasan udang yang tertinggi didapatkan pada perlakuan B, disusul perlakuan C, perlakuan A, dan terakhir perlakuan D. Meskipun dari hasil analisis ragam tidak terlihat adanya perbedaan perlakuan frekuensi vaksinasi, akan tetapi analisis secara deskriptif memperlihatkan bahwa frekuensi vaksinasi empat kali sebulan (perlakuan B) memberikan tingkat sintasan udang yang tertinggi yaitu 91,5\% Hal ini juga didukung dengan tingginya produksi udang pada perlakuan B dengan frekuensi vaksinasi dua kali sebulan yaitu sebanyak $84,0 \mathrm{~kg}$. Untuk lebih jelasnya data produksi tambak tersebut untuk masing-masing perlakuan pada akhir penelitian dapat dilihat pada Gambar 1 .

Analisis ragam terhadap tingkat produksi udang pada akhir penelitian, tidak memperlihatkan adanya perbedaan yang nyata antar perlakuan. Akan tetapi secara deskriptif perlakuan B memberikan tingkat produksi yang lebih tinggi yaitu sebesar 84,0 kg; perlakuan D sebesar 78,6 kg; perlakuan C sebesar 79,2 $\mathrm{kg}$; dan perlakuan A sebesar 71,04 kg. Tingkat produksi udang yang dihasilkan tidak berkorelasi positif dengan nilai sintasan yang ada. Hal ini dapat dilihat pada perlakuan $D$ yang meskipun produksinya lebih tinggi dibandingkan dengan perlakuan A dan C akan tetapi sintasannya lebih rendah jika dibandingkan dengan kedua perlakuan tersebut. Hal ini dimungkinkan karena ukuran (size) udang yang dihasilkan lebih besar pada perlakuan D tersebut. Tingginya sintasan pada perlakuan B disebabkan setelah divaksinasi ulang sebanyak dua kali jumlah antigen yang diberikan sudah cukup untuk menginduksi pembentukan antibodinya seperti yang dikemukakan oleh Raa et al. (1992) yang menyatakan bahwa udang memerlukan stimulasi yang berulang untuk dapat mengaktifkan sistem immunnya. Dalam hal ini 
Tabel 1. Sintasan (\%) udang windu pada akhir penelitian dengan frekuensi vaksinasi yang berbeda

Table 1. Survival rate (\%) of tiger shrimp for the different vaccination frequency to the end of study

\begin{tabular}{ccc}
\hline $\begin{array}{c}\text { Perlakuan } \\
\text { Treatments }\end{array}$ & $\begin{array}{c}\text { Sintasan (\%) } \\
\text { Survival rate (\%) }\end{array}$ & $\begin{array}{c}\text { Rata-rata (\%) } \\
\text { Mean value (\%) }\end{array}$ \\
\hline A1 & 83.3 & $74.97^{\mathrm{a}}$ \\
A2 & 50.0 & \\
A3 & 91.6 & \\
\hline B1 & 83.5 & $91.5^{\mathrm{a}}$ \\
B2 & 93.9 & \\
B3 & 97.0 & $79.7^{\mathrm{a}}$ \\
\hline C1 & 88.3 & \\
C2 & 53.8 & \\
C3 & 97.0 & $78.9^{\mathrm{a}}$ \\
\hline D1 & 93.4 & \\
D2 & 86.6 & \\
D3 & 56.7 & \\
\hline
\end{tabular}

Keterangan (Note):

$A=$ vaksinasi empat kali sebulan (four time of vaccination a month)

$\mathrm{B}=$ vaksinasi dua kali sebulan (two time of vaccination a month)

$\mathrm{C}=$ vaksinasi sekali sebulan (once of vaccination a month)

$\mathrm{D}=$ tanpa vaksin/kontrol (non vaccination)

Angka yang diikuti dengan huruf superscript sama menyatakan tidak berbeda nyata (the number followed the same alphabet means not significantly different) $(P>0.05)$

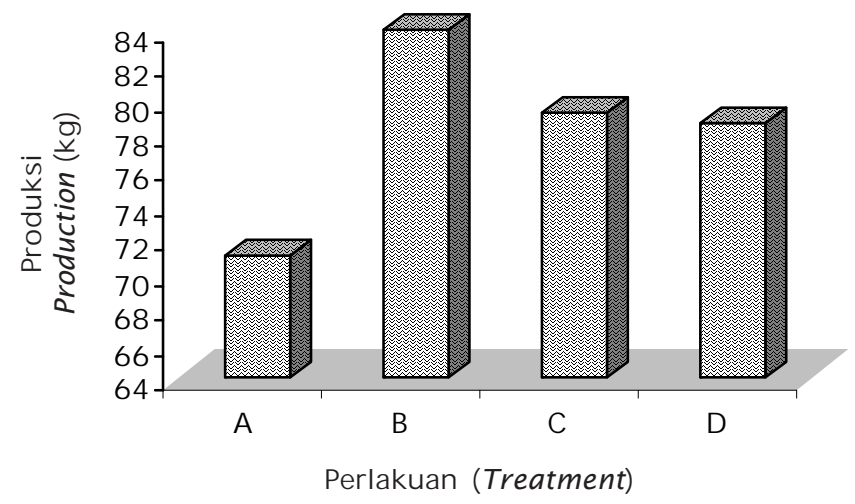

Gambar 1. Produksi udang windu untuk setiap perlakuan pada akhir penelitian Figure 1. Production of tiger shrimp for every treatment at the end of study 
mekanisme kerja immunostimulan bakterin adalah dengan menekan kerja hemosit dalam mengaktivasi sel- sel fagosit.

Frekuensi vaksinasi empat kali sebulan pada perlakuan A memiliki sintasan yang terendah terhadap semua perlakuan yang diberikan. Hal ini kemungkinan disebabkan dosis vaksinasi yang diberikan melebihi kemampuan udang untuk dapat mengaktifkan sistem immunnya sehingga terjadi in efficiency. Pada kondisi ini bakterin yang diberikan kepada udang tidak lagi menjadi immunostimulan akan tetapi kemungkinan menjadi immunostressor dan dikhawatirkan akan bersifat toksik pada udang, seperti yang dikemukakan Kresno (1996) bahwa reaksi kekebalan akan berlangsung tidak wajar atau berlebihan apabila jumlah antigen yang masuk ke dalam tubuh relatif tinggi, sehingga pada keadaan yang demikian lebih cenderung akan menimbulkan kerusakan jaringan. Namun dari hasil pengamatan terhadap sampel udang secara morfologi belum ditemukan adanya gejala kerusakan jaringan.

Rendahnya sintasan udang pada perlakuan tanpa vaksinasi disebabkan tidak adanya respon kekebalan di dalam tubuh udang terhadap serangan bakteri. Hal ini didukung oleh pernyataan Takahashi et al. (2000) bahwa pada kelompok larva udang yang diberi vaksin (sel bakteri) persentase hidupnya lebih baik dibandingkan dengan kelompok larva yang tidak diberi vaksin.
Pengamatan terhadap tingkat sintasan yang ada pada beberapa perlakuan menunjukkan adanya variasi yang cukup besar, seperti yang terlihat pada perlakuan A dan perlakuan C. Hal ini kemungkinan disebabkan distribusi bakterin yang dicampurkan pada pakan tidak tersebar merata, atau respon udang pada pakan yang diberikan tidak sama.

\section{Perkembangan Populasi Bakteri Vibrio sp.}

Pengamatan terhadap kesehatan udang juga dilakukan secara bakteriologis yaitu dengan mengamati perkembangan populasi bakteri Vibrio sp. baik pada media air tambak maupun pada sedimen tambak. Hasil pengamatan terhadap perkembangan populasi bakteri pada media air tambak selama penelitian dapat dilihat pada Gambar 2.

Gambar 2 memperlihatkan perkembangan populasi bakteri selama penelitian untuk semua perlakuan yang diberikan termasuk pada daerah tandon, saluran pemasukan (inlet), dan saluran pengeluaran (outlet) berada pada keadaan yang masih normal dan tidak membahayakan bagi organisme yang dibudidayakan, yaitu berkisar antara $10^{2}-10^{3} \mathrm{cfu} /$ $\mathrm{mL}$. Pada tambak-tambak yang terserang penyakit umumnya didapatkan populasi bakteri mencapai $10^{4}-10^{7} \mathrm{cfu} / \mathrm{mL}$. Rendahnya populasi bakteri pada tambak penelitian kemungkinan disebabkan adanya pengaruh penggunaan kapur dolomit yang dilakukan

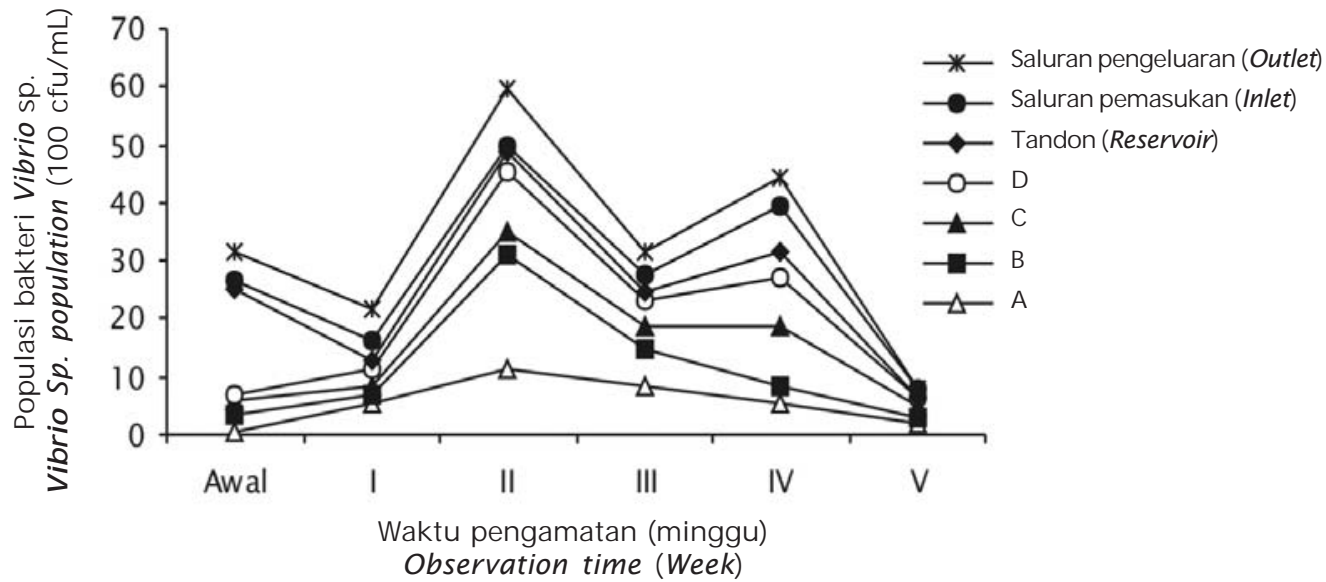

Gambar 2. Perkembangan populasi bakteri Vibrio sp. dalam media air tambak setiap dua minggu selama penelitian

Figure 2. Development of Vibrio sp. population during experiment in pond water every two week 
setiap dua kali perminggu setelah ganti air di mana fungsi dari kapur dolomit ini selain sebagai desinfektan juga sebagai buffer dan penjernih air. Selain itu, manajemen air juga dilakukan dengan penggunaan tandon air (Tompo, 2003).

Untuk perkembangan populasi bakteri Vibrio sp. pada sedimen tambak selama penelitian dapat dilihat pada Gambar 3.

Perkembangan populasi bakteri Vibrio sp. pada sedimen tambak selama penelitian juga memperlihatkan keadaan yang tidak membahayakan bagi lingkungan dan perkembangan udang budi daya (Gambar 3), meskipun pada saluran pengeluaran (outlet) pada sampling ke1, 2, 4, dan 6 memperlihatkan jumlah populasi Vibrio sp. yang berada pada nilai $10^{4}-10^{5}$. Hal ini dapat terjadi karena saluran pengeluaran merupakan tempat pembuangan air yang telah digunakan pada proses budi daya selama penelitian berlangsung, sehingga banyak terkandung sisa-sisa pakan yag tidak termanfaatkan oleh udang dan juga sisa- sisa ekskresi udang yang dapat menjadi penyebab tingginya populasi Vibrio sp. pada lokasi tersebut. Kondisi ini tidak membahayakan baik bagi lingkungan maupun bagi udang budi daya, karena air tersebut akan diresirkulasi secara alamiah pada sumber pemasukan air.

\section{Kualitas Air}

Hasil pengamatan terhadap parameter kualitas air selama penelitian disajikan pada Tabel 2.

Kualitas air tambak selama penelitian untuk beberapa parameter pengamatan masih berada pada kisaran yang layak untuk budi daya udang (Tabel 2 ).

Hasil pengamatan terhadap salinitas air tambak berada pada kisaran 19-40 ppt, kisaran ini masih layak untuk budi daya udang windu di mana udang merupakan organisme euryhaline yang dapat hidup dan menyesuaikan diri pada salinitas tersebut meskipun kisaran salintas yang baik untuk kehidupan udang adalah 27-32 ppt. Tingginya kisaran salinitas yang diperoleh disebabkan selama penelitian dilakukan pada kondisi masih musim kemarau.

Kadar $\mathrm{pH}$ perairan kisaran yang didapatkan juga masih berada pada kondisi yang layak dan sesuai $(7,5-8,7)$ untuk kehidupan udang, di mana menurut Wickins (1979), udang akan mengalami mortalitas yang tinggi jika $\mathrm{pH}$ air berada di bawah 5,0. Suhu air tambak juga masih berada pada kisaran normal kecuali menjelang awal musim hujan (Januari 2005) pada pukul $07.00-11.00$ siang mencapai $39^{\circ} \mathrm{C}$ sehingga mengakibatkan stres pada udang

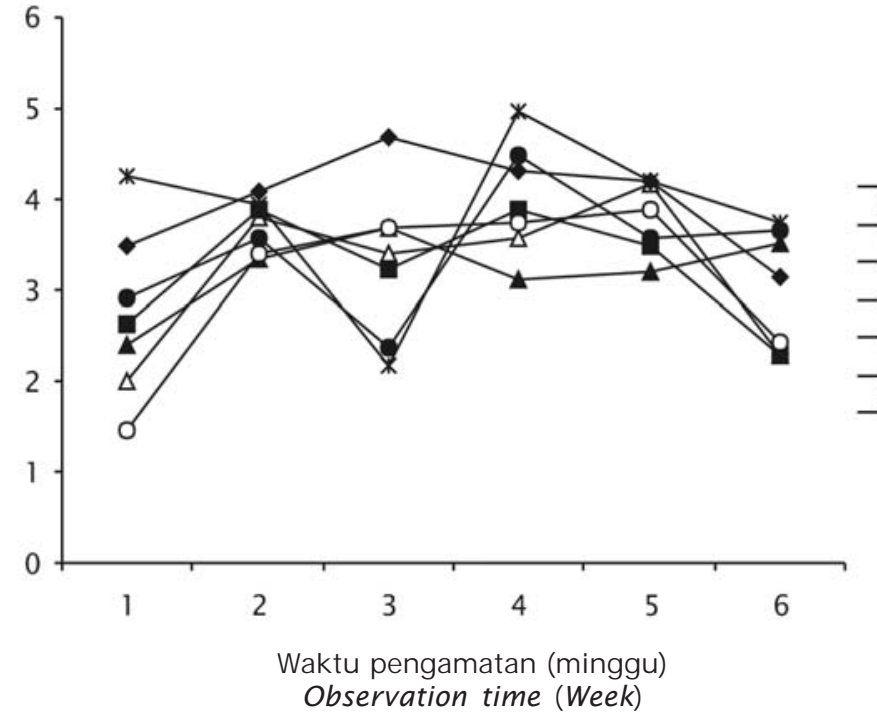

Gambar 3. Perkembangan populasi bakteri Vibrio sp. dalam sedimen tambak setiap 2 minggu selama penelitian

Figure 3. Development of tiger shrimp during experiment in pond sediment every two week observation 


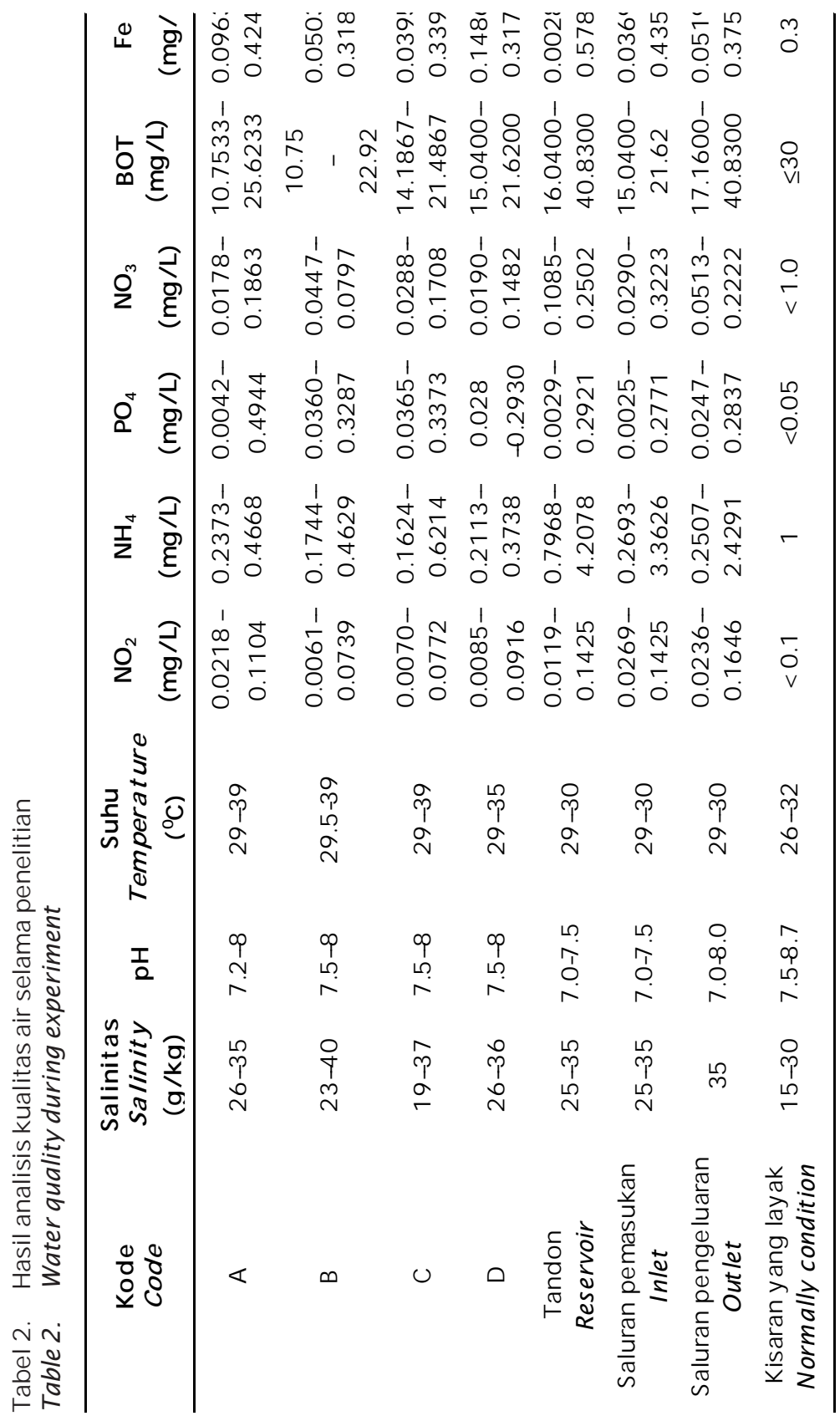


yang ditandai dengan gejala udang ke pinggir pematang. Untuk mengatasi hal tersebut dilakukan pergantian air pada tambak. Suhu air turut mempengaruhi respon kekebalan tubuh, di mana proses pembentukan antibodi pada suhu rendah akan terhenti atau antibodi yang terbentuk sangat rendah (Pasaribu, 1993).

Kandungan amoniak selama penelitian baik pada perlakuan maupun pada tandon cukup tinggi dan berada di atas kisaran yang layak untuk budi daya udang. Hal ini kemungkinan disebabkan pada petak pemeliharaan selama penelitian terjadi proses budi daya di mana input pakan yang diberikan tidak semuanya dimanfaatkan oleh udang, sehingga menyebabkan tingginya penimbunan bahan organik. Demikian juga feses yang dihasilkan oleh udang peliharaan menyebabkan berfluktuasinya kadar amoniak pada setiap petakan selama masa pemeliharaan. Kondisi demikian juga menyebabkan berkembangnya bakteri termasuk Vibrio sp. Tingginya amoniak pada tandon air disebabkan tandon air hanya merupakan tempat penampungan air dari sumber air yang juga berfungsi menstabilkan air selama kurang lebih 3 hari sebelum dialirkan ke saluran pemasukan (inlet) yang akan dialirkan ke setiap petakan. Hal lain yang mempengaruhi fluktuasi amoniak pada tandon air disebabkan pada saat pengambilan sampel sering bersamaan waktunya dengan pasang tinggi sebagai sumber air.

Untuk kadar nitrit, nitrat, fosfat, dan besi semuanya masih berada pada kisaran yang layak. Kandungan bahan organik total (BOT) selama penelitian pada semua perlakuan cukup tinggi yaitu $(10,7533-40,8300 \mathrm{mg} / \mathrm{L})$ di mana hal ini dapat meningkatkan populasi dari mikroorganisme termasuk yang bersifat patogen, udang mengalami stres, nafsu makan berkurang, serta mudah terserang penyakit utamanya penyakit parasiter (Tompo et al., 1997). Hal ini dapat di atasi dengan menggunakan aerasi pada tambak- tambak intensif dan segera melakukan pergantian air.

\section{Komposisi Jenis Fitoplankton dan Zooplankton}

Untuk komposisi jenis fitoplankton dan zooplankton selama penelitian dapat dilihat pada Tabel 3.

Jenis fitoplankton dan zooplankton yang teramati selama penelitian merupakan jenis yang umum dan biasa didapatkan pada lokasilokasi pertambakan yang merupakan jenis fitoplankton dan zooplankton dari air payau yang dapat dimanfaatkan sebagai pakan alami bagi udang budi daya.

\section{KESIMPULAN}

1. Frekuensi vaksinasi dua kali sebulan merupakan frekuensi vaksinasi yang tepat untuk mengaktifkan sistem kekebalan udang, dengan produksi tertinggi $84 \mathrm{~kg}$.

2. Sintasan tertinggi didapatkan pada perlakuan frekuensi vaksinasi dua kali sebulan $(91,5 \%)$, menyusul perlakuan vaksinasi sekali sebulan $(79,7 \%$, perlakuan tanpa vaksinasi $(78,9 \%)$, dan terendah pada

Tabel 3. Komposisi jenis fitoplankton dan zooplankton setiap perlakuan selama penelitian

Table 3. Phytoplankton and zooplankton composition during experiment every treatment

\begin{tabular}{llccccc}
\hline \multirow{2}{*}{ Plankton } & \multicolumn{7}{c}{ Kode perlakuan (Treatment code ) } \\
\cline { 2 - 7 } & A & B & C & D & Tandon & Inlet \\
\hline Fitoplankton & Oscilatoria & Oscilatoria & Nitzhia & Oscilatoria & Nitzhia & Oscilatoria \\
Phytoplankton & Acartia & Anabaena & Oscilatoria & Anabaena & Anabaena & Nitzhia \\
& Pleurosigma & Nitzhia & Chaetoceros & Pleurosigma & Amphora & Anabaena \\
& Anabaena & & Anabaena & Biddulphia & Pleurosigma & \\
& Biddulphia & & Amphora & Nitzhia & & \\
\hline Zooplankton & Bmphora & & Biddulphia & Chaetoceros & & \\
Zooplankton & Acartia & Acartia & Acartia & Acartia & Acartia & Acartia \\
\hline
\end{tabular}


perlakuan vaksinasi empat kali sebulan $(71,97 \%$ ).

\section{DAFTAR PUSTAKA}

Anonim. 2003. http:// www.dkp.go.id [20 Oktober 2003].

Anonim. 2005. Statistik Produksi Perikanan Budidaya. http:/ / www.dkp.go.id

Atmomarsono, M., M.I. Madeali, Muliani, dan A. Tompo. 1993. Kasus Penyakit Udang di Kabupaten Pinrang dalam Hanafi, A., M. Atmomarsono., S. Ismawati (Eds.). Prosiding Seminar Hasil Penelitian Perikanan Budidaya Pantai. Maros 16-19 Juli. p. 35- - 40.

Brock, T.D., M.T. Madigan, J.M. Matinko, and J. Parker. 1994. Biology of Microorganism. Seventh Edition. Prentice Hall International, Inc. 909 pp.

Chanratchakol, P., J.F. Turnbull, C. Limsuwan, and S.F. Smith. 1995. Third Shrimp Health Management. Training Hand-Book. The Aquatic Animal Health Research Institute. Departement of Fisheries Kasetsart University Campus. Bangkok. p. 287- - 289.

Effendie, M.I. 1979. Metode Biologi Perikanan. Yayasan Dewi Sri. Bogor. 112 pp.

Gaspersz, V. 1991. Metode Perancangan Percobaan. Penerbit Armico. Bandung.

Kamiso, H.N. 1996. Metode Pencegahan Hama dan Penyakit Ikan Karantina dengan Penggunaan Vaksin. Makalah Disampaikan Pada Seminar Hama dan Penyakit Ikan Karantina. 13 Desember 1996. Cipanas. Bogor. 18 pp.

Kresno, B.S. 1996. Immunologi. Diagnosis dan Prosedur Laboratorium. Edisi III. Fakultas Kedokteran Univ. Indonesia. Jakarta. 347 pp.

Madeali, M.I., M. Atmomarsono, A. Tompo, dan Muliani. 1993. Studi Kasus Penyebab Kematian Udang Windu, Penaeus monodon di Tambak Intensif. J. Pen. Budidaya Pantai. 9(4): 23-28.

Madigan, M.T., J.M. Martinko, and J. Parker. 2000. Brock: Biology of Microorganism. Ninth Edition. Prentice Hall. Southern Illionis University Carbondale. 900 pp.

Pasaribu, F. 1993. Pelet Bervaksin terhadap Aeromonas Hidrophyla. Fakultas Kedokteran Hewan. IPB. Bogor. 12 pp.

Raa, J., G. Roersted, R. Engstad, and B. Robertsen. 1992. The Use of Immunostimulant of
Increase Resistance of Aquatic Organism to Microbial Infections. Diseases in Asian Aquaculture I. Fish Health Section. Asian Society. Manila Philippines. p. 39-50.

Supriyadi, H. 1990. Pencegahan penyakit bakterial pada usaha budidaya perikanan. Bahan Kuliah Pada Pelatihan Karantina Ikan. 21 Mei - 4 Agustus. 1990. Ciawi. Bogor. $11 \mathrm{pp}$.

Steel, R.G.D. and J.H. Torrie. 1989. Principles and Procedure of Statistic a Biometrical Approach. Second Edition. Mc Graw Hill International Book Company. New York. 633 pp.

Tompo, A., M.I. Madeali, dan Muliani. 1997. Pengaruh konsentrasi BOT terhadap patogenisitas parasit pada udang windu. Laporan Hasil Penelitian Peningkatan Kesehatan Lingkungan Tambak Udang. p. 18-36.

Tompo, A. 2002. Penggunaan vaksin virus dan beberapa jenis bakteri patogen pada udang skala lab dan lapangan. Laporan Teknis Balai Riset Perikanan Budidaya Air Payau. $31 \mathrm{pp}$.

Takahashi, Y., M. Kondo, T. Itami, T. Honda, H. Inagawa, T. Nishizawa, G. Soma, and Y. Yokomizho. 2000. Enhancement of diseases resistance against penaeid acute viremia and induction of virusinactivating activity in hemolimph of kuruma shrimp, Penaeus Japonicus by oral administration of pontoea agglomerans lipopolyscacharide (bakterin). Fish and Shelfish Immunology. p. 151- - 152.

Tompo, A. 2003. Penggunaan vaksin virus dan beberapa jenis bakteri patogen pada udang skala lab dan lapangan (Lanjutan). Laporan Teknis Balai Riset Perikanan Budidaya Air Payau. 41 pp.

Tompo, A., M. Atmomarsono, M.I. Madeali, dan Muliani. 1993. Prevalensi dan Intensitas Ektoparasit Pada Udang Windu, Penaeus monodon di Tambak Sulawesi Selatan. J. Pen. Budidaya Pantai. 9(3): 111-118.

Wickins, J.F. 1979. The Effect of Reduce pH On Carapace Calcium, Strontium and Magnesium Levels in Rapidly Growing Prawn. Penaeus monodon Fabr. Aquaculture. 41: 49-60. 